\title{
3Dコンテンツの機能性解明への取り組み
}

\author{
○ 河合 隆史（早稲田大学）
}

\section{Ergonomics approaches for functional examination of stereoscopic content}

Takashi KAWAI (Waseda University)

\section{1.はじめに}

立体視映像（3D）に関する人間工学研究分野で は、3D映画の世界的な定着に伴い、従来とは異な るアプローチが求められるようになってきた。具 体的に、実際の利活用を想定した知見へのニーズ が高まっており、例えば、観察に伴う疲労をはじ め、長時間・長期間の観察による影響や、年齢層 といったユーザの属性との関連など、未知な点は 多い。

そこで筆者らは、3Dの人間工学研究の事例や知 見の共有を目的として、2010年度より日本人間工 学会に3D人間工学研究部会を設立・運営している。 表1に、これまでに当該部会が開催した、主要な シンポジウムについて示した。

表1 3D人間工学研究部会による主なシンポジウム

\begin{tabular}{|c|l|}
\hline 開催年月 & \multicolumn{1}{|c|}{ 開催の場・シンポジウムのテーマ } \\
\hline 2010年12月 & $\begin{array}{l}\text { 日本人間工学会 関東支部第40回大会・ } \\
\text { 3D元年の人間工学 }\end{array}$ \\
\hline 2011年06月 & $\begin{array}{l}\text { 日本人間工学会 第52回大会・立体映像 } \\
\text { の人間工学 - 安全性と快適性 }\end{array}$ \\
\hline 2011年10月 & $\begin{array}{l}\text { Digital Content Expo 2011・立体映像 } \\
\text { の快適視聴に関する新たなパラダイム }\end{array}$ \\
\hline 2011年12月 & $\begin{array}{l}\text { 日本人間工学会 関東支部第41回大会・ } \\
\text { ソーシャルメディアと立体視 }\end{array}$ \\
\hline 2013年06月 & $\begin{array}{l}\text { Digital Content Expo 2012・3Dテレビ } \\
\text { に関する取り組みと今後の展開 } \\
\text { ※ 総務省との共催 }\end{array}$ \\
$\begin{array}{l}\text { 日本人間工学会 第54回大会・立体映像 } \\
\text { の認知・情動特性 }\end{array}$ \\
\hline
\end{tabular}

表1から、当該部会のシンポジウムのテーマが、 3Dの安全性や快適性から、その特性や利活用へと 変遷してきていることが分かる。

本稿では、3Dの人間工学研究における筆者らの 最近の取り組みとして、認知・情動の観点による 機能性の解明について紹介寸る。

\subsection{Dの情動効果}

筆者らは「3Dは、2Dよりも感動するのか?」と いう問いに対して、継続的に検討を行っている。

「アバター（20世紀フォックス，2009）」など 世界的に著名な3D映画を対象として、感情の表出 シーンにおいて両眼視差にどのような特徵がみら れるか、視差分析を用いて検討した ${ }^{1 \sim 2)}$ 。結果か ら、視差設計に基本感情毎の一定の傾向がみられ たことから、これを、感情を喚起する異なる画像 に適用した際の影響について、実験的な検討を 行った ${ }^{3)}$ 。大規模な画像セットInternational Affective Picture System (IAPS) ${ }^{4)}$ 用い、元 画像である2D条件と、各画像に含まれる単眼情報 に基づいて両眼視差を付加した3D条件、さらに感 情毎の視差設計を反映したE3（Emotional 3D）条 件間で、情動価と覚醒度に与える影響を比較した。 結果から、3D化と視差設計の反映によって、いず れの感情分類においても、覚醒度を増進する可能 性が示唆された（図1）。

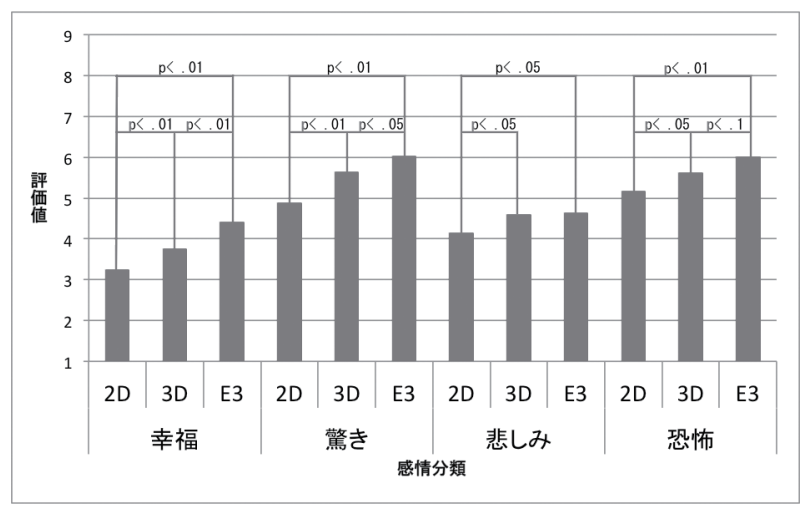

図1＼cjkstart条件・感情分類別による覚醒度の評価結果 ${ }^{3)}$

\section{3Dの認知効果}

情動効果と併行して、「3Dは、記憶や学習に効 果的か?」という問いについても、継続的に取り 組んできた。筆者らは、映像内の一部分の夕に交 差性の両眼視差を付加した「局所3D」を提案し、 
その特性について認知的観点から検討を行ってい る。具体的に、単純図形を用いた視覚探索課題で のパフォーマンスの向上 ${ }^{5)}$ や自然画像内の特定 対象に対する注視時間の延長 ${ }^{6)}$ 、外科手技教育用 コンテンツの視認性の改善7)などを認めている。

こうした結果を受けて、局所3Dの注意・記憶一 の影響について、チェンジブラインドネス現象を 課題とした実験的検討を行った ${ }^{8)}$ 。チェンジブラ インドネス課題での変化の検出には、注視に加え、 画像を一時的に記憶して比較する認知的な作業が 求められる ${ }^{9)}$ 。2D条件、画像全体に視差を付加し た3D条件、変化対象を局所 $3 \mathrm{D}$ 化した条件と、変化 対象以外の一部に視差を付加した妨害局所3D条件 を設定した結果を、図2に示した。図2から、局所 3D条件では探索時間の短縮が、妨害局所3D条件で は延長が、それぞれ認められる。このことは、局 所3Dが、注意・記憶への影響源になり得ることを 示唆している。

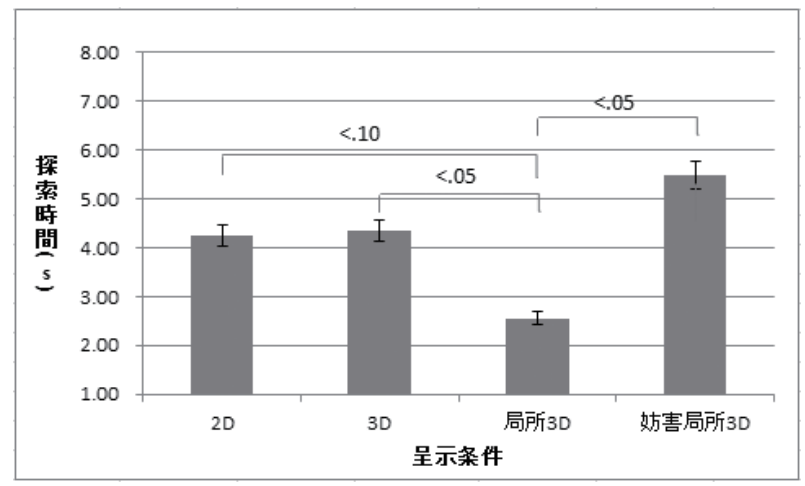

図2 条件別による探索時間の計測結果 ${ }^{8)}$

\section{4.おわりに}

現在、筆者らは、上述の実験的検討について、 新たな目的や条件を設定した追試を進めると同時 に、得られた知見の利活用を進めている。3Dの情 動効果では映画、3Dの認知効果では広告や教材と いったコンテンツを想定し、実現へ向けた取り組 みを行っている。

3Dコンテンツの機能性に関する取り組みや知見 は、研究者だけでなく、ユーザにとっても有益で あることから、国内外の状況を広く発信していく 必要があると考えている。そこで当該部会では、 ハリウッドを拠点とした業界団体である国際3D協 会の日本部会 ${ }^{10)}$ と連携し、3Dコンテンツの機能性 に関する情報提供を目的としたウェブサイト ${ }^{11)}$ 構築した。
当該部会の設立期間は2014年度で終了するが、 国内外の関連団体と連携していくことで、当該サ イトの運営を継続したいと考えている。

\section{Acknowledgements}

本稿で紹介した研究の一部は、科学研究費補助 金・基盤研究（A）「3次元空間における時空間の 知覚的歪夕に関する研究」および 同基盤研究

(C)「立体視映像コンテンツの情緒表現と機能」 の補助を受けて行われた。

\section{参考文献}

1）富山勇也，他：“ハリウッド3D映画の視差分析 と表現方法の検討 (1)”，人間工学，Vol. 48, 特別号，pp. 418-419， 2012.

2）平原正広，他：“ハリウッド3D映画の視差分析 と表現方法の検討 (2)”，人間工学，Vol. 48, 特別号, pp. 420-421，2012.

3）熱田大貴, 他： “立体映像の視差量の操作と情 緒表現への影響”, 人間工学, Vol. 49, 特別号, pp. 40-41, 2013.

4) Lang, P. J. , 他: “International affective picture system (IAPS): Affective ratings of pictures and instruction manual”, Technical Report A-8 University of Florida, 2005.

5）小井土慶久，他：“局所立体映像の提案と基礎 的評価”, 人間工学, Vol. 46, 特別号, pp. 478-479, 2010.

6）小井土慶久，河合隆史：“局所立体映像表現の 認知特性の評価”, 人間工学, Vol. 47, 特別号, pp. 252-253, 2011.

7）小井土慶久，他：“局所立体映像を用いた外科 手技教材の試作と評価”, 人間工学, Vol. 48, 特別号, pp. 434-435，2012.

8）上道寛子，他：“特定領域一の両眼視差の付加 と注意・記憶への影響”, 人間工学, Vol. 49, 特別号，pp. 34-35， 2013.

9) Rensink, R. A. : “Change Detection”, Annual Review of Psychology, Vol.53, pp. 245-277, 2002.

10) http://www. i3ds. jp/

11) http://www. naruhodo3d. jp/ 